\title{
Strike Actions and Pre-Service NCE Teachers' Learning Outcomes: Differential Effects of Gender and Schools of Affiliation
}

\author{
TAIWO, Ruth, O. A. \\ Curriculum and Instruction \\ School of Education, Emmanuel Alayande College of Education, Oyo, Oyo State \\ OGUNLADE, O. O. Ph.D. \\ Educational Psychology \\ School of Education, Emmanuel Alayande College of Education, Oyo, Oyo State \\ ADESINA, Abiodun E. Ph.D. \\ Science and Mathematics Unit, General Studies Education, \\ School of Education, Emmanuel Alayande College of Education, Oyo, Oyo State
}

\begin{abstract}
The effect of repeated closures of schools and institutions of learning due to strike actions is debilitating and casts a dark shadow on the educational sector in Nigeria. This paper thus examines the effect of strike actions on the learning outcomes of pre-service teachers in Emmanuel Alayande College of Education, Oyo adopting a mixed method of research with qualitative and quantitative approaches, sample randomly 371 NCE 1, 2, and 3 pre-service teachers that witnessed the saga of incessant industrial actions using two instruments for data collection, Effects of Strike Action on Students Learning Outcomes Questionnaire (ESASLQ, $\mathbf{r}=\mathbf{0 . 7 9}$ ) and Effects of Strike Action on Students Learning Outcomes Interview Scale (ESASOI, $\mathbf{r}=\mathbf{0 . 7 2}$ ). Data was analysed using frequency counts and percentages, t-test and ANOVA. There was significant pre-service teachers' perceived effects of strike action on pre-service teachers' learning outcomes $(\overline{\mathrm{x}}=66.12 ; \mathrm{df}=326 ; \mathrm{t}=96.63 ; \mathrm{p}<.05)$. The pre-service NCE teachers' perceived effects of strike action was significant on their lecture attendance $(\overline{\mathrm{x}}=15.30 ; \mathrm{df}=326 ; \mathrm{t}=101.77 ; \mathrm{p}<.05)$, writing lecture note $(\bar{x}=14.70 ; d f=326 ; t=96.57 ; p<.05)$., preparing for tests and assignment $(\bar{x}=14.60 ; d f=326$; $\mathrm{t}=85.31 ; \mathrm{p}<.05)$, preparation for examinations $(\overline{\mathrm{x}}=14.26 ; \mathrm{df}=326 ; \mathrm{t}=79.56 ; \mathrm{p}<.05)$, respect for constituted authority $(\overline{\mathrm{x}}=13.98 ; \mathrm{df}=326 ; \mathrm{t}=77.92 ; \mathrm{p}<.05)$ and academic results $(\overline{\mathrm{x}}=13.57 ; \mathrm{df}=326 ; \mathrm{t}=60.14 ; \mathrm{p}<.05)$. The effect was significantly differentiated by their schools of affiliation $\left(\mathrm{F}_{(5,285)}=34.36, \mathrm{p}<.05\right)$. It was recommended that government should conceive education as social function and fund it appropriately to forestall future catastrophe. Keywords: Strike action, Pre-Service NCE teachers' learning outcomes, Gender, Schools of affiliation
\end{abstract} DOI: $10.7176 /$ RHSS/10-11-06

Publication date:June 30th 2020

\section{Introduction}

There are certain vital factors that contribute to the process of successfully developing proficiency in learning among other possible influences, these factors include: age, aptitude, motivation and attitude, personality, cognitive style, hemisphere specialization, learning strategies, teaching and learning contexts, and inputs and interaction (Miller 2016; Larsen-Freeman \& Long 1991). The first seven factors (i.e. from Age-Learning Strategies) can be grouped as internal factors, while the last two factors (i.e. Teaching and Learning Contexts, and Inputs and Interactions) are grouped as external factors. The internal factors referred to above, are those factors which are inherent to the student, or which the language student brings into the learning situation; while the external factors are those factors that characterize the environment and learning situation of the students.

It is posited in this paper that while the incessant disruption of classroom and instructional learning through industrial actions such as strikes may tend more towards the extrinsic, there is sufficient evidence to show that extrinsic negativities owing to industrial protests, lockdowns and strikes within the Nigerian educational system have far reaching effects on other forms of internal or intrinsic factors for the learner, one of which is the motivation of the student in the learning process. This in turn negatively impacts on the student's productivity and the observed learning outcomes after the duration of the study period. Added to this, are the obvious external impediments to learning that strikes portend, some of which include the disruption of classroom activities and the teacher-student instructional medium, disjointed learning process for the students which limits cumulative coherence, and loss of academic time which puts pressure on the academic calendar and leads to a hasty conclusion of academic sessions, also leading to a protraction of duration of study for most students in public institutions of learning in Nigeria.

Productivity is a measure of how well resources are utilized to produce output, and it is defined as a ratio of outputs to inputs (Darra 2006). This implies that to manage productivity is to achieve more outputs for the same 
input. Establishing the negative impact that industrial strikes by education worker unions have on the learning outcomes of students is an empirical thrust for concluding that there is a directly proportionate relationship between a permanent resolution of stiff labour conflicts and improvement in current pre-service teachers' learning outcomes.

Industrial strikes in Nigeria's educational system is an effort by employees to withhold work so that the employer will make greater concessions at the bargaining table (Ivancevich, 2007). It "is a concerted and temporary withholding of employee services from the employer for the purpose of exacting greater concessions in the employment relationship than the employer is willing to grant at the bargaining table" (Isiaka 2001). Strikes in Nigeria are the result of the actions and counteractions of the academic staff unions to the unyielding attitude of government towards the fulfilment of past agreements on conditions of service, salaries/allowances, adequate funding of education and other sundry issues. Unions such as Academic Staff Union of Universities (ASUU), Academic Staff Union of polytechnics (ASUP), College of Education Academic Staff Union (COEASU), and even the Nigerian Union of Teachers (NUT) and other affiliate unions in the Education sector at the Primary, Secondary and Tertiary levels all result to embarking on strikes as an urgent resort to get the attention of government and a balance of power between their staff and the government at the negotiation and implementation table. Since most engagements between government and labour unions are not often fruitful, the Nigerian educational system has been subject to the debilitating effects of these strikes for many years.

Strikes by workers are global occurrence. Strikes are caused by many factors, such as suboptimum remuneration, unfavourable working hours, high malpractice insurance premiums, poor working conditions, harassment by clienteles (students).

These industrial strikes range from weeks to months and sometimes well over a year. Many have contended that strikes ought to be the last resort, but have often become the first resort of workers, however, labour unions on the other hand insist that strikes are the last resort when all else fails to yield results (Armstrong, 2004). The resulting effect of these protracted strikes is the disorientation, disenchantment, loss of interest, poor academic performance and poor retention among students. This shows intrinsic changes in attitude and motivation as a result of influence from the hostile environment to learning, which industrial strikes portend for our educational system. In a study of 154 respondents by Thomas (2013), the following reflect the perception of respondents:

- $\quad 97.4 \%$ of respondents agree that students make less progress in their academic plans as a result of labor strikes;

- $\quad 90.2 \%$ agree that strikes destabilize students and decrease their eagerness to learn;

- $\quad 85 \%$ agree that learning environment is less conducive during a labor strike;

- $\quad 97.4 \%$ agree that labor strikes have strong and negative effects on student learning;

- $\quad 85 \%$ agree that labor strikes allow less time for faculty to prepare and teach;

- $\quad 71.5 \%$ agree that Labor strikes reduce the level of student participation in the classroom;

- $\quad 77.3 \%$ agree that students perform better when they have more class days.

These responses correlate with a 2016 publication by the Higher Education Quality Council of Ontario in which more than two thirds of the student respondents reported feeling uncertainty about whether or not to keep up with their studies during a strike, and a significant proportion of students reported general laziness and a disruption to their good study habits. Approximately $85 \%$ of students from both universities under study indicated that they had learned less than they should have in a course as a result of the strike. In another study by Jaume and Willén (2017), Argentina is reported to have experienced about 1,500 strikes by teachers between 1983 and 2014 , and the study concludes that teacher industrial actions is a feature of public education systems across the globe, however, it identifies that strikes have serious long-term adverse consequences on the attainment of educational goals and outcomes.

Industrial strikes and student productivity or learning outcomes from the behaviourists' perspective of productivity theory, behaviour can be explained by extrinsic factors, just as behavioural conditioning can be effectively used in universal learning processes. However, behaviourists believe that behavioural patterns are determined only by environmental effects, though critics have held that this view is too deterministic, but if we consider that the behaviourist approach focuses on the here and now, it helps us to temper the criticism in the light of how environmental factors are currently shaping the learning process from empirical facts. Thus, while it may be contended that people can make choices about their behaviours and thus determine their future outcomes through nurturing, it may seem empirically reasonable to state that environmental limitations for instance can pose more decisive and significant threats to set objectives where there are other prevalent or competing impediments, and that it takes a combination of other exceptional factors to surmount serious degrees of limiting factors.

The behaviourist believe that the learning process is fundamental in determining who people and can be used to achieve specific goals across board, thus whatever distorts or disrupts learning, distorts and disrupts the quality of personal development, learning, proficiency and productivity (Studymoose, 2016; Kompa, 2015). While much of the pilot studies have been carried out on animals, which may suffice to say human behaviour may not always be so determined strictly, but ex post facto studies are beginning to reveal that behaviourism may after all be useful in predicting behavioural changes under certain circumstances like incessant industrial strikes, and by extension 
be used to predict changes in learning outcomes or student productivity.

"Teacher industrial action is a prevalent feature of public education systems across the globe; during the past few years teacher strikes have been observed in countries as diverse as Argentina, Brazil, Canada, Chile, China, Colombia, France, Germany, India, Israel, Italy, Lebanon, Mexico, Russia, Spain and the United States (e.g. Seattle, East St. Louis, Pasco, Prospect Heights and Chicago). A shared belief among policymakers across several of these countries is that teacher strikes are detrimental to student learning due to Its negative effect on instructional time" (Baker, 2013 in Jaume \& Willén, 2017)

Empirically, Jaume and Willén (2017) exploit cross-cohort variation in the prevalence of teacher strikes within and across provinces in Argentina in a difference-in-difference framework to examine how exposure to teacher strikes during primary school affects long-run outcomes find evidence of a decline in hourly wage, an increase in unemployment, an increase in the probability of not working or studying and a decline in the skill levels of the occupations into which students sort and that children of adults who were exposed to teacher strikes during primary school also experience adverse educational attainment effects.

Monogbe and Monogbe (2019) examine the extent to which Academic Staff Union of the University (ASUU) strikes influences tertiary educational system in Nigeria. The study adopts the descriptive research design where questionnaires were distributed to 600 students of the four target universities in Rivers and Ekiti state. Due to the incessant industrial action of strike by the academic staff union of university (ASUU) in Nigeria, empirical findings has provided evidence that student performance drop drastically, the quality of education and students' performance is negatively influenced by incessant ASUU strike such that increase in ASUU strike is capable of decreasing student performance in the Nigerian universities, that incessant strike actions culminate into the erosion of academic quality, robbing off academic time from school administrators and upon resuming from a strike, academic work is bound to the rushed. The present study thus investigates strike action and pre-service NCE teachers' learning outcomes the differential effects of gender and schools of affiliation.

\section{Statement of the problem}

The last administration in Oyo state fomented and fuelled disruptions in all facets of the sectors of economy including education, a social governmental function, there was epileptic salaries payment ranges from $75 \%$ to $25 \%$ and sometimes $0 \%$ allowances which compelled incessant industrial actions that compulsorily put the college gates a close. Despite the hustles and tussles, the college missed no academic sessions for the past six years of the pandemonium. What then are the aftermaths of these inordinate and unconscionable strike actions? Apart from the apparent sharp drops in the students' enrolment, the aftershocks of students' dramatic pummel in both the academic and attitudinal performance of the pre-service teachers and invariable low level of educational graduates produced at the college. The present study thus investigate the pre-service NCE teachers' perceived effects of strike actions on their learning outcomes vis-à-vis the differential effects of their gender and schools of affiliation.

\section{Research Questions}

The following questions were answered in the course of the study:

i. Does strike action affect pre-service teachers' learning outcomes?

ii. What are the effects of strike action on pre-service teachers' lecture attendance, writing lecture note, preparing for tests and assignment, preparation for examinations, respect for constituted authority and academic results?

\section{Hypotheses}

The following hypotheses were tested at 0.05 level of significance:

Ho1: There is no significant effect of strike actions on pre-service teachers' learning outcomes.

Ho2: There is no significant effects of strike action on pre-service teachers' lecture attendance, writing lecture note, preparing for tests and assignment, preparation for examinations, respect for constituted authority and academic results.

Ho3: There is no significant difference of effect of strike actions on pre-service teachers' learning outcomes based on gender.

Ho4: There is no significant difference of effect of strike actions on pre-service teachers' learning outcomes based on schools of affiliation.

\section{Methodology}

\section{Research Design}

The study adopted mixed method of qualitative and quantitative approaches (concurrent triangulation). The design employed thematic approach using focus group interview (FGI) and ex-post facto design in quantitative design. 
All the variables of the study, the dependent (pre-service NCE teachers' learning outcomes) and the independent (strike actions, gender, schools of affiliation) are already available in the field; instrument was designed to tap the data for empirical analysis (Kerlinger \& Lee, 2000; Stroud, 2018).

\section{Population of the Study}

All the pre-service NCE teachers of the Emmanuel Alayande College of Education constitute the population of the study. The total population is 3713 with 735 in 100 level, 1310 in 200 level and 2368 in 300 level.

\section{Sample and Sampling Technique}

Proportionate sampling technique was adopted to select one-third of the pre-service teachers in each strata of the schools of affiliation. 34 were selected randomly from school of Arts and Social Sciences, 15 from Early Childhood Care and Education, 14 from Education, 43 from Languages, 69 from Science and 63 pre-service teachers randomly sampled from the School of Vocational and Technical Education totaling 371 samples for the study.

\section{Instrumentation}

Two research instruments: Effects of Strike Action on Students Learning Outcomes Questionnaire (ESASLQ). The 50 constructed-item instrument on the pre-service teachers' six universe of contents of lecture attendance, writing lecture note, preparing for tests and assignment, preparation for examinations, respect for constituted authority and academic results was given for experts' scrutiny which reduces it to 25 items for construct and content validity. The final draft was administered on 30 pre-service NCE teachers in another neighbouring institution, the collated data subjected to Cronbach's Alpha Statistical analysis which yielded 0.79 index. The positively worded items on the scales were scored 4, 3, 2 and 1 for Strongly Agree, Agree, Disagree and Strongly Disagree respectively while the reverse in the case for the negatively worded items. The second instrument is Effects of Strike Action on Students Learning Outcomes Interview Scale (ESASOI) with 18 items on the effects of strike actions on the pre-service teachers' lecture attendance, writing lecture note, preparing for tests and assignment, preparation for examinations, respect for constituted authority and academic results. The scale was given to expert for content and construct validity, 12 items survived scrutiny, the draft was administered on 30 pre-service teachers similar to the sample for the study, the collated data were subjected to Inter-rater reliability which yielded a value of 0.72 .

\section{Procedure for Data Collection}

The ESASLQ and ESASOI were administered concurrently on the sample of the study 327 of the administered instruments were appropriately filed and returned for data collection and analysis.

\section{Method of Data Analysis}

The socio-demographic attributes of the respondents were presented in tables of frequency counts and percentages, thematic analysis was adopted to answer the research questions while parametric statistics of t-test and Analysis of Variance (ANOVA) was adopted to determine the effects of strike action on students learning outcomes.

\section{Results}

Table 1: Respondents distribution by gender and schools of affiliation

\begin{tabular}{lcc}
\hline \multicolumn{1}{c}{ Variables } & Frequency & Percentage (\%) \\
\hline Gender & & \\
Male & 157 & 48.00 \\
Female & 170 & 52.00 \\
Total & $\mathbf{3 2 7}$ & $\mathbf{1 0 0 . 0 0}$ \\
School of Affiliation & & \\
Arts \& Sos & 67 & 20.50 \\
ECCPED & 75 & 22.90 \\
Education & 19 & 5.80 \\
Languages & 59 & 18.00 \\
Science & 67 & 20.50 \\
Voc \& Tech & 40 & 12.20 \\
Total & $\mathbf{3 2 7}$ & $\mathbf{1 0 0 . 0 0}$ \\
\hline
\end{tabular}

Table I shows that $157(48.00 \%)$ of the respondents were male while the remaining $170(52.00 \%)$ were female, 67 (20.50\%) were Arts and Social Sciences students, 73 (22.90\%) studies Early Childhood Care and Education, 19 (5.80\%) studies Education, 59 (18.00\%) Languages, 67 (20.25\%) studies Sciences while the remaining 40 $(12.20 \%)$ studies Vocational and Technical Education. 


\section{Answers to research questions}

i. Does strike action affect pre-service teachers' learning outcomes?

The response of the students to the interview revealed that the strike action really affect their their teaching-learning process which invariably mar their learning outcomes. Out of the 327 pre-service teachers interviewed, $293(89.60 \%)$ agreed to the fact that the strike action did affect their learning outcomes while a comparatively low 34 (11.40\%) disagreed that the strike action did not affect their learning outcomes.

ii. What are the effects of strike action on pre-service teachers' lecture attendance, writing lecture note, preparing for tests and assignment, preparation for examinations, respect for constituted authority and academic results?

The majority of the pre-service teachers averred that the lingered strike action affected their lecture attendance which was epileptic, their note taking which was erratic, their preparation for tests and assignment which lacked being systematic, cumulative or even diagnostic, their preparation for examination which was panic and frightening announced which most of the times prompt their affront against the school management as well as the teaching and non-teaching staff and invariably culminated in their poor learning outcomes.

\section{Hypotheses testing}

The following hypotheses were tested at 0.05 level of significance:

Ho1: There is no significant pre-service NCE teachers' perceived effect of strike actions on pre-service teachers' learning outcomes.

Table2: T-test analysis of pre-service NCE teachers' perceived effect of strike actions on pre-service teachers' learning outcomes

\begin{tabular}{|l|l|l|r|c|c|c|l|}
\hline & $\mathrm{N}$ & Mean & Std. Deviation & $\mathrm{T}$ & df & Sig. (2-tailed) & Remarks \\
\hline strike action effects & 327 & 86.1237 & 14.89545 & 98.632 & 326 & .000 & $* \mathrm{~S}$ \\
\hline
\end{tabular}

From Table 2, there is significant pre-service NCE teachers' perceived effect of strike actions on pre-service teachers' learning outcomes (Mean=66.12; $\mathrm{N}=327$; $\mathrm{df}=326 ; \mathrm{t}=96.63 ; \mathrm{p}<.05$ ). Therefore, the null hypothesis that says there is no significant pre-service NCE teachers' perceived effect of strike actions on pre-service teachers' learning outcomes was not accepted.

Ho2: There are no significant pre-service NCE teachers' perceived effects of strike action on pre-service teachers' lecture attendance, writing lecture note, preparing for tests and assignment, preparation for examinations, respect for constituted authority and academic results.

Table3: T-test analyses of pre-service NCE teachers' perceived effects of strike action on pre-service teachers' lecture attendance, writing lecture note, preparing for tests and assignment, preparation for examinations, respect for constituted authority and academic results

\begin{tabular}{|c|c|c|c|c|c|c|c|}
\hline & $\mathrm{N}$ & Mean & Std. Deviation & $\mathrm{t}$ & df & Sig. (2-tailed) & Remarks \\
\hline lecture_attendance & 327 & 15.3048 & 2.66897 & 101.774 & 326 & .000 & $* \mathrm{~S}$ \\
\hline writing_lecture_note & 327 & 14.7035 & 2.71081 & 96.572 & 326 & .000 & $* \mathrm{~S}$ \\
\hline preparing_for_test_ass & 327 & 14.5963 & 3.07006 & 85.314 & 326 & .000 & $* \mathrm{~S}$ \\
\hline preparing_for_exam & 327 & 14.2589 & 3.15060 & 79.556 & 326 & .000 & $* \mathrm{~S}$ \\
\hline respect_constituted_authority & 327 & 13.9785 & 3.23410 & 77.920 & 326 & .000 & $* \mathrm{~S}$ \\
\hline Academic_results & 327 & 13.5772 & 4.06338 & 60.144 & 326 & .000 & $* \mathrm{~S}$ \\
\hline
\end{tabular}

Table 3 revealed that there are significant pre-service NCE teachers' perceived effects of strike action on preservice teachers' lecture attendance $(\mathrm{Mean}=15.3048 ; \mathrm{N}=327 ; \mathrm{df}=326 ; \mathrm{t}=101.774 ; \mathrm{p}<.05)$, writing lecture note $(\mathrm{Mean}=14.7035 ; \mathrm{N}=327 ; \mathrm{df}=326 ; \mathrm{t}=96.572 ; \mathrm{p}<.05)$., preparing for tests and assignment $(\mathrm{Mean}=14.5963 ; \mathrm{N}=$ $327 ; \mathrm{df}=326 ; \mathrm{t}=85.314 ; \mathrm{p}<.05)$, preparation for examinations $($ Mean $=14.2589 ; \mathrm{N}=327 ; \mathrm{df}=326 ; \mathrm{t}=79.556$; $\mathrm{p}<.05)$, respect for constituted authority $($ Mean $=13.9785 ; \mathrm{N}=327 ; \mathrm{df}=326 ; \mathrm{t}=77.920 ; \mathrm{p}<.05)$ and academic results $($ Mean $=13.5772 ; \mathrm{N}=327 ; \mathrm{df}=326 ; \mathrm{t}=60.144 ; \mathrm{p}<.05$ ). Therefore, the null hypothesis that says there are no significant pre-service NCE teachers' perceived effects of strike action on pre-service teachers' lecture attendance, writing lecture note, preparing for tests and assignment, preparation for examinations, respect for constituted authority and academic results was not accepted.

Ho3: There is no significant difference of pre-service NCE teachers' perceived effect of strike actions on preservice teachers' learning outcomes based on gender. 
Table 4; T-test analysis of difference of pre-service NCE teachers' perceived effect of strike actions on pre-service teachers' learning outcomes based on gender

\begin{tabular}{|l|l|l|l|r|l|l|l|l|}
\hline & student gender & N & Mean & Std. Deviation & Df & T & Sig & Remarks \\
\hline \multirow{2}{*}{ strike_action_effects } & male & 157 & 85.8440 & 14.55300 & 325 & -.310 & .757 & NS \\
& female & 170 & 86.3867 & 15.25435 & & & & \\
\hline
\end{tabular}

Table 4 indicated that the difference of pre-service NCE teachers' perceived effect of strike actions on preservice teachers' learning outcomes based on gender is not significant $(\mathrm{N}=327 ; \mathrm{df}=325 ; \mathrm{t}=-.310 ; \mathrm{p}>.05)$. Therefore, the null hypothesis that says there is no significant difference of pre-service NCE teachers' perceived effect of strike actions on pre-service teachers' learning outcomes based on gender was accepted.

Ho4: There is no significant difference of pre-service NCE teachers' perceived effect of strike actions on preservice teachers' learning outcomes based on schools of affiliation.

Table 5.0: Analysis of variance of difference of pre-service NCE teachers' perceived effect of strike actions on pre-service teachers' learning outcomes based on schools of affiliation.

\begin{tabular}{|l|r|r|r|r|r|}
\hline & Sum of Squares & df & Mean Square & F & Sig. \\
\hline Between Groups & 24196.045 & 5 & 4839.209 & 34.353 & .000 \\
Within Groups & 40147.501 & 285 & 140.868 & & \\
Total & 64343.546 & 290 & & & \\
\hline
\end{tabular}

Table 5 revealed that there is no significant difference of pre-service NCE teachers' perceived effect of strike actions on pre-service teachers' learning outcomes based on schools of affiliation $\left(\mathrm{F}_{(5,285)}=34.36, \mathrm{p}<.05\right)$. Therefore, the null hypothesis that says there is no significant difference of pre-service NCE teachers' perceived effect of strike actions on pre-service teachers' learning outcomes based on schools of affiliation was not accepted. To know the direction and magnitude of the difference based on the school of affiliation scheffe posthoc test was carried out in Table 5.1

Table 5.1: Scheffe posthoc test of difference of pre-service NCE teachers' perceived effect of strike actions on pre-service teachers' learning outcomes based on schools of affiliation

\begin{tabular}{|c|c|c|c|c|c|}
\hline \multirow[t]{2}{*}{ student affiliation } & \multirow[t]{2}{*}{$\mathrm{N}$} & \multicolumn{4}{|c|}{ Subset for alpha $=0.05$} \\
\hline & & 1 & 2 & 3 & 4 \\
\hline $\begin{array}{l}\text { Sciences } \\
\text { languages } \\
\text { Ass } \\
\text { voc \& tech } \\
\text { Education } \\
\text { Eccped } \\
\text { Sig. }\end{array}$ & $\begin{array}{r}60 \\
59 \\
67 \\
29 \\
9 \\
67\end{array}$ & $\begin{array}{l}74.1833 \\
81.3220 \\
84.5522\end{array}$ & $\begin{array}{l}81.3220 \\
84.5522 \\
88.9310\end{array}$ & $\begin{array}{r}88.9310 \\
96.4444 \\
.334\end{array}$ & $\begin{array}{r}96.4444 \\
100.0149 \\
.935\end{array}$ \\
\hline
\end{tabular}

From Table 5.1, pre-service NCE teachers in school of ECCPED had the highest (100.0149) perceived effects of strike actions on pre-service teachers' learning outcomes followed by those in school of education (96.4444), followed by those in the school of Vocational and Technical Education (88.9310), followed by school of Arts and Social sciences (84.5522), followed by those in school of Languages (81.3220) while the students in Sciences had the least (74.1833) perceived effects of strike actions on pre-service teachers' learning outcomes.

\section{Discussion}

From the answered research questions, it was revealed that the pre-service NCE teachers perceived a strong effects of the incessant strike actions on their learning outcomes. The majority of the pre-service teachers claimed that the lingered strike action affected their lecture attendance which was epileptic, their note taking which was inconsistent and irregular, their preparation for tests and assignment which lacked being systematic, cumulative or even diagnostic, their preparation for examination which was anxiety-based and terrifyingly announced that most of the times prompt their disrespect and outrage against the school management as well as the teaching and non-teaching staff and invariably culminated in their poor learning outcomes. This submission is in tandem with the findings of Baker (2013) in Jaume and Willén (2017) that teacher strikes are detrimental to student learning due to its negative effect on instructional time.

From the tested hypotheses, it was indicated that there is significant pre-service NCE teachers' perceived effect of strike actions on pre-service teachers' learning outcomes. This means that the perception held by the preservice NCE teachers on their learning outcomes strongly impact their learning outcomes in the college. This can be attributed to the incessantness and continuous exposure of these students to series of industrial actions. This finding finds supports in Jaume and Willén (2017) that children of adults who were exposed to teacher strikes during primary school also experience adverse educational attainment effects. Also corroborating the finding is Monogbe and Monogbe (2019) that student performance drop drastically, that quality of education and student 
performance is negatively influenced by incessant ASUU strike such that increase in ASUU strike is capable of decreasing student performance in the Nigerian universities, that incessant strike actions culminate into the erosion of academic quality, robbing off academic time from school administrators and upon resuming from a strike, academic work is bound to the rushed. There are significant pre-service NCE teachers' perceived effects of strike actions on pre-service teachers' lecture attendance, writing lecture note, preparing for tests and assignment, preparation for examinations, respect for constituted authority and academic results. This is in consonance with the findings of Thomas (2013) that $97.4 \%$ of respondents agree that students make less progress in their academic plans as a result of labor strikes; $90.2 \%$ agree that strikes destabilize students and decrease their eagerness to learn; $85 \%$ agree that learning environment is less conducive during a labor strike; $97.4 \%$ agree that labor strikes have strong and negative effects on student learning; $85 \%$ agree that labor strikes allow less time for faculty to prepare and teach; $71.5 \%$ agree that Labor strikes reduce the level of student participation in the classroom; $77.3 \%$ agree that students perform better when they have more class days.

Noted from the tested hypothesis also is the fact that the effects of strike actions on the pre-service NCE teachers transcend issue of gender, as gender, being male or female does not significantly influence the pre-service teachers' perception of impacts of industrial action on learning outcomes. Both the male and the female pre-service teachers hold the strong perception of significant impact of industrial action on learning outcomes. But, the preservice teachers' perception of the effects of strike actions on their learning outcome was significant based on schools of affiliation, the pre-service NCE teachers in school of ECCPED had the highest perceived effects of strike actions on pre-service teachers' learning outcomes followed by those in school of education, followed by those in the school of Vocational and Technical Education, followed by school of Arts and Social sciences, followed by those in school of Languages while the students in Sciences had the least perceived effects of strike actions on pre-service teachers' learning outcomes. This can be explained based on the fact that the majority of students in sciences are already of high academic capability and efficacy than their contemporaries in other schools making them to feel the impacts of the strike actions less than othet schools. Those pre-service teachers in ECCPED, Education, Arts and Social Sciences, Languages and Vocational and Technical Education tend to be of lower capability and efficacy when compared to their counterparts in sciences.

\section{Conclusion}

The impacts accruable to learning outcomes in college of education by strike action is highly significant affecting negatively the pre-service NCE teachers' lecture attendance, writing lecture note, preparing for tests and assignment, preparation for examinations, respect for constituted authority and academic results. The effects of the past industrial actions in the college was not sullied by gender rather the pre-service teachers' school of affiliations significantly influenced the impacts of the industrial actions on the learning outcomes. The paper thus concludes that the incessant industrial strikes as external factors have a negative impact on the attitudinal or motivational responses of students to the learning process and impedes their learning outcomes, hereby giving room for the behaviouralists' perspective to be used as a justified way of predicting general students' attitude to studies and their motivational levels during strike actions - which are expected to be low.

\section{Recommendations}

On the basis of the results of this study, the following recommendations were given:

- Government should consider highly important regular payment of salaries and allowances of workers in tertiary institutions as well as other public workers in the state so as to curb incessant industrial actions;

- Education should top priority list and even when resources is dwindling, workers should not be suffered at all and by extension, institution would be on without unnecessary break;

- Government should always honour any agreement reached with institution unions and by this, peaceful coexistence among education stakeholders would be entrenched;

- $\quad$ Periodic seminars on topics like study habit, self-concept, cognitive restructured etc. should be organized to students and this would invariably promotes positive attitude to academic work by students of other schools as found in school of science;

- Counseling psychologists should be allowed to function maximally in the school and this would curb antisocial behavior among learner;

- Provision should be made in Nigerian constitution sanctioning any government who fails to pay salaries and allowances as when due;

- Government should conceive education as social function and fund it adequately to foster future catastrophe.

\section{References}

Christine M. Wickens, Cathy Labrish, Azar Masoumi, Lisa M. Fiksenbaum, Esther R. Greenglass (2016). "Understanding the Student Experience of a University Labour Strike: Identifying Strategies to Counter 
Negative Impact". Higher Education Quality Council of Ontario, (C) Queens Printer for Ontario, 2016.

David, J. and Alexander, W. (2017). “Long-run Effects of Teacher Strikes: Evidence from Argentina”. CEDLAS, October 2017. ISSN 1853-0168. Edition, Singapore.

Hogg, M. and Vaughan G. (2005). Social Psychology (4 ${ }^{\text {th }}$ Edition) London Prentice-Hall

Isiaka S.B (2001). The continued relevance of strike as a form of industrial action in Isiaka, S. B. (2001). The continued relevance of strike as a form of industrial action in Nigeria Humanity. Jos Journal of General Studies, 3(2), $36-44$.

Ivancerich, J. M. (2017). Human resource management (10 ${ }^{\text {th }}$ ed.) McGraw Hill, International Edition, Singapore.

Jaume, D. \& Willén, A. (2017). The Long-run Effects of Teacher Strikes: Evidence from Argentina.DocumentodeTrabajoNro.217,https://www.www.cedlas.econo.unlp.edu.a

Kompa, J. (2015). "Strengths and Limitations of Behaviorism for Human Learning". Retrieved from https://joanakompa.com/2015/05/02/strengths-and-limitations-of-behaviorism-for- learning/

Larsen-Freeman, D. \& M. Long. (1991). “An Introduction to Second Language Acquisition Research”. London: Longman. Chap. 6: 153-219.

Lightbown, Patsy .M. \& Nina Spada (2013). “How Languages Are Learned”. Oxford University Press, 2013 Print.

Miller, A. (2016). "9 Factors That Influence Language Learning”, A Whitby School Publication, November 2016, Lake Avenue Greenwich.

Monogbe, B. O. and Monogbe, T. G. (2019). ASUU Strike and Nigerian Educational System: An Empirical Investigation of the Nigerian Tertiary Institution. American Journal of Social Sciences and Humanities, 4(1), $56-67$

Ogbette, A. and J. Eke, 2017. University Industrial action in Nigeria and student perf ormance. International Journal of Education and Humanities, 5(9): 23-32.

Olusegun, A.J., 2014. ASUU strikes and academic performance of students in ekiti state university Ado-Ekiti. International Journal of Management and Business Research, 4(1): 1934

Sejcoba, L. (2006). Pohladnakvalitu Zivota dosipievojucich Bratislav: Album

StudyMoose (2016, Jun 07). "Advantages and Disadvantages of the Behaviourist Approach". Retrieved from https://studymoose.com/advantages-and-disadvantages-of-the- behaviourist-approach-essay

Thomas, I. (2013). "Effects of Labor Strikes on the Quality of University Education in Nigeria". Walden University, October 2013. 